\title{
HOW EFFECTIVE IS THE FREE TRADE AGREEMENT IN SOUTH ASIA? AN EMPIRICAL INVESTIGATION
}

\author{
Amirul Islam ${ }^{1}$ \\ Harry Bloch ${ }^{2}$ \\ Ruhul Salim ${ }^{2 *}$ \\ ${ }^{1}$ Department of Economics \\ Faculty of Social Sciences \\ University of Chittagong \\ Chittagong, BANGLADESH \\ Email: amiruli@yahoo.com \\ ${ }^{2}$ School of Economics \& Finance \\ Curtin Business School \\ Curtin University \\ Perth WA 6845, AUSTRALIA
}

Acknowledgement: We are grateful to the anonymous referee and the editor Professor M. C. Sawyer for helpful comments and suggestions which tremendously improved the presentation and the quality of the paper. However, the authors are solely responsible for any error remains.

Corresponding author: School of Economics \& Finance, Curtin Business School, Curtin University, Perth, WA 6845. Phone: +61 89266 4577, Fax: +61 89266 3026, E-mail: Ruhul.Salim@ @bs.curtin.edu.au 


\section{HOW EFFECTIVE IS THE FREE TRADE AGREEMENT IN SOUTH ASIA? AN EMPIRICAL INVESTIGATION}

\section{Introduction}

The domino effect of regional trading agreements (RTAs) that occurred throughout the world during the nineties came to South Asia in 1993 when it formed the South Asian Preferential Trading Agreement (SAPTA). The agreement was later converted into the South Asian Free Trade Agreement (SAFTA) in 2004 and made operational after two years in 2006. In spite of their geographic and cultural proximity, South Asian countries trade less with each other than they do with countries outside of the region. Like other regional blocs, a major goal of regional integration policies in South Asia has been to bring growth in intra-regional trade flows. However, the formation of a free trade bloc itself does not ensure increased intra-bloc trade.

If a region is characterized by similar production structure across the countries and heavily depends on a small number of export items, it is most likely that their trade ties will be with countries outside the region. This type of extra-regional dependence for export can be observed in the oil exporting gulf region and to some extent in the primary resource dependent countries. For South Asia, two added impediments on the way of intra-regional trade expansion are the shallowness of integration and the non-economic factors, like cross-border insurgency problems. Exporters are less willing to go through the complicated rules of origin procedure in order to access the thin tariff preference, and governments of the region fear that deep integration will jeopardize national sovereignty.

Amid all these uncertainties about the effectiveness of the regional integration, it is worthwhile to investigate how regional trade flows have responded to the recently formed SAFTA trade bloc. The purpose of this article is to investigate the efficacy of preferential trade liberalization in changing the observed trade pattern by identifying the determinants of bilateral trade flows among the South Asian countries using econometric techniques, as well as supportive qualitative economic analysis. Though in its nascent stage, some data are now available to provide an ex-post evaluation of the performance of this bloc. Using these actual data, we find no empirical evidence of trade creation among SAFTA members, which is not surprising given that tariff concessions in SAFTA are small and are offset by complicated rules of origin procedure.

In contrast to the existing literature on regional integration where only the potential for increasing intra-regional trades among the members in the post-agreement period is investigated, the current study examines the changes in trade flow pattern between the South Asian countries

and the rest of the world in the post-SAFTA period as well. Here, a substantial and statistically significant increase in exports from SAFTA members to the rest of the world is found. Also, 
several panel strategies are used to check the sensitivity of the results against the assumptions of the estimation strategies. As several key coefficient estimates are found to differ across estimation methods, policymakers in South Asia need to use care in relying on the results from empirical studies, including our own, in formulating their trade policies.

The rest of the paper is organized as follows. Section 2 provides a brief overview of the regional trade pattern of the South Asian countries. A selection of current literature that relates bilateral trade flows to regional integration is analyzed in Section 3. The dataset and the methodology of the study are explained in Section 4, followed by the estimation results and their interpretation in Section 5. Finally, Section 6 concludes the article.

\section{Intra-Regional Trade in South Asia}

Compared to other regions of the world, South Asia, because of political and other non-economic reasons, has not put much effort into developing the potential gains from economic cooperation. World Bank (2004) shows that intra-regional trade in South Asia is discriminated against by the countries in the region compared to trade with the rest of the world. Back in 1948 intra-regional trade in South Asia was about 19 per cent of total trade, which by 1974 had reduced to less than 4 per cent and has remained so for the last three decades.

One might think that it should be natural for geographically proximate countries to trade more with one another. However, Deardorff (2001) shows that the importance of distance in determining trade flows may be outweighed by the network effect of trade. If it happens, for example, that a larger portion of population from Bangladesh migrated and settled in the USA than in Nepal, the network effect in terms of exploring market will be stronger between the US and Bangladesh. As a result, the real cost of doing business or trade cost will be lower for this latter pair of countries. This has in fact been the case for most of the South Asian countries in explaining their changed pattern of trade. Reduced trade costs for distant countries have transformed the local comparative advantage to a global comparative advantage phenomenon.

The changing pattern of trade flow within the region is shown in Table A1 in the appendix and is summarized in Figure 1. Figure 1 shows the percentage of intra-regional trade for individual countries on the left-hand vertical axis, while the average intra-regional trade across all South Asian countries is shown on the right-hand axis. It is evident from a cursory view of the table and the figure that the smaller economies of South Asia - especially, Nepal, Sri Lanka, and Bangladesh - have become more regionally oriented over time. Nepal, for example, has increased her regional average trade from 25 per cent in the 1980 s to 58 per cent in the recent decade, while Sri Lanka has shown an improvement from 6 per cent of total trade to over 16 per cent over the same period. For Bangladesh these figures are 5 per cent and 10 per cent, respectively. The two dominant economies of India and Pakistan remain indifferent by 
conducting only about 2 per cent of their total trade within the region for the past three decades, so that the average intra-regional trade across all countries is less than 3 per cent in the 1980s and only rises to about 4 percent by the 2000s. Making these two countries more regionally integrated would have enormous impact on the trade flow of this region.

Figure 1: Intra-Regional Trade in South Asia

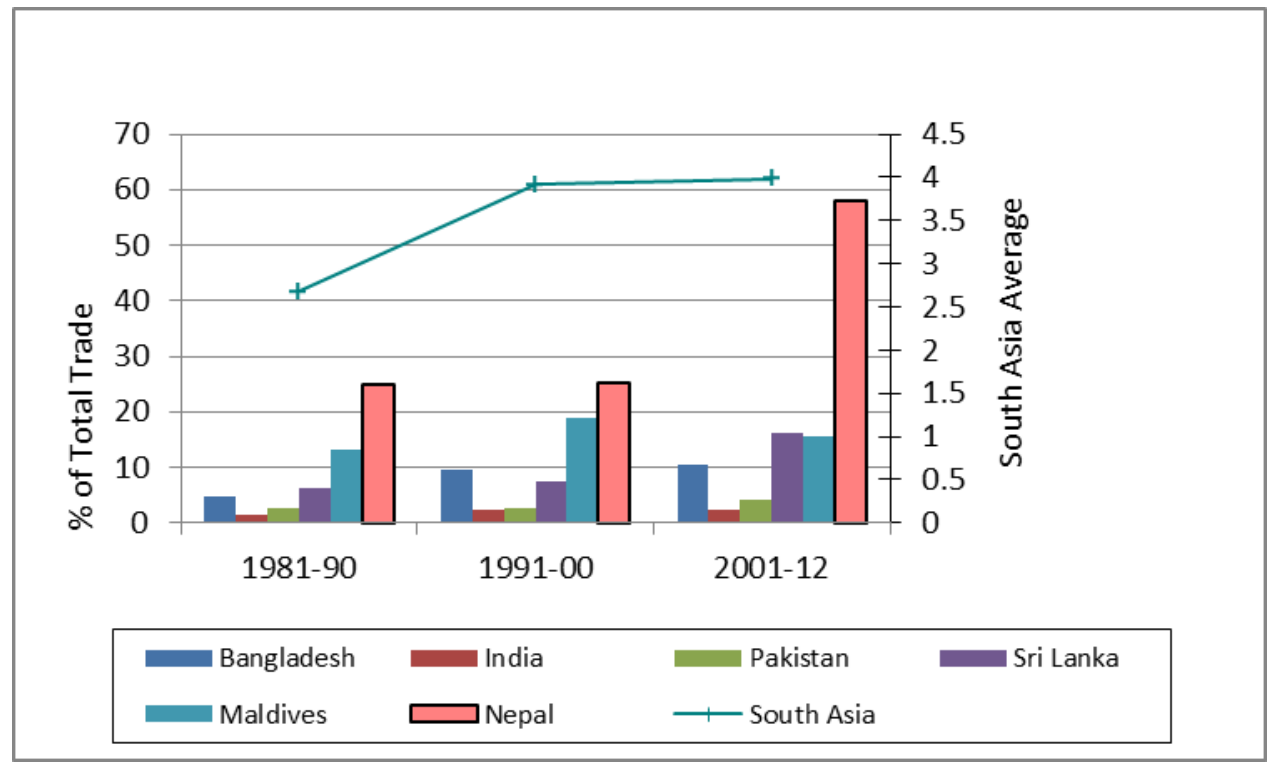

Source: Based on the Direction of Trade Statistics (2013), IMF

Bilateral trade flows between the two large partners are suffering from what is termed by Eichengreen and Irwin (1998) as the 'hysteresis' effect of bilateral trade flows, whereby the history of previous trade flows determine the current trade pattern. The effect seems reasonable for India and Pakistan, because once exporters incur fixed costs to develop distribution network in the foreign markets, they need to exploit the market for a long period of time to recoup profits. Perception of possible future disruptions in the relationship (war or political tensions) discourages exporters to make investment expenditures for markets that are subject to such disruptions.

The fact that a small portion of trade occurs within the region has led some trade theorists (e.g. Panagaraya 1996) to conclude that the countries in this region are not natural trading partners, hence the possibilities of trade diversion from regional integration is substantial. However, Bhagwati and Panagariya (1996) offer a systematic analysis showing that the amount of pre-bloc trade among the members has no role to play in the welfare implications of forming a discriminatory trading area. In addition to that, a large volume of trade in South Asia occurs informally through the extensive and naturally porous border region. If these unofficial trade figures are taken into consideration, as well as the fact that official trade has increased since the 
1990s, then the countries may look more like natural trading partners. Moreover, as the nature of production and the trade structure are changing throughout the world, the prospect of trade expansion through regional cooperation is gaining importance. Athukorala and Yamashita (2008) find that fragmentation of trade is growing at a faster rate than total world manufacturing trade, and making intra-regional dependence more important than ever.

\section{Review of Selected Literature}

Empirical evidence regarding the effects of RTAs on bilateral trade is mixed and tends to depend on the characteristics of member countries. The instability of the RTA coefficients across cases is reported in Word Bank (2005) and Cipollina and Salvatici (2010). Because of the wide variety of available estimates of the trade effects of RTAs, Cipollina and Salvatici (2010) use a metaanalysis technique to investigate the true effects of RTAs. Utilizing a total of 1827 estimates available over 85 previous studies, the authors show that, amid variability of estimates, preferential agreements considered as a whole have positive effects on trade flows for the members. Frankel et al (1996) is ambiguous about the impact of RTAs, as the relevant coefficients in their study are insignificant, but Wonnacott (1996) is more optimistic about the positive effects of RTA by stating that when there are scale economies an RTA can lead to welfare improvement even in the presence of trade diversion.

The European Union is the most prominent of all the regional blocs in terms of the depth and breadth of integration it has attained so far. European Commission (1997) investigates the trade creation and trade diversion effects of the single market program (SMP) in Europe. These issues are examined empirically for 15 three-digit SITC sectors using both econometric and general equilibrium methods. The study shows that in most of the sectors the EU market has been more open, leading to trade creation instead of trade diversion. In addition to higher trade flows, the SMP program has contributed to improved competitiveness, with the price-cost margin falling by 3.9 per cent across these sectors since 1992. Glick and Rose (2002) narrow down the investigation to the effects of the monetary union on trade flows and find almost doubling of the overall trade flow from this source only.

South Asia took much of its inspiration from the success story of the free trade bloc of the neighbor region, Southeast Asia, which formed AFTA (Association of South East Asian Nation's Free Trade Area) in 1992. Bun et al (2007) show that an enormous increase in bilateral trade flows within this region is not merely driven by economic growth of this region, but is in fact a consequence of its regional integration policy. More particularly, within an extended gravity model that accounts for unobserved heterogeneity, these authors show that AFTA has contributed 9 per cent to bilateral export growth per annum within the region after the inception of the free trade agreement. Sawyer et al (2010) explain that a large portion of the increased 
intra-Southeast Asian trade represents intra-industry trade. The rising share of manufacturing export and increasing research and development expenditure along with increasing openness of the region is supporting a fragmented production structure in this region.

Literature on the impact of regional trade liberalization, especially on trade flows, in the context of South Asia is sparse. Hassan (2001) proclaims to be the first to apply the gravity type of model to evaluate the viability of a South Asian free trade bloc. Rahman et al (2006) follow the two-stage regression methodology suggested by Coulibali (2004) to assess the impact of the South Asian and other RTAs on bilateral trade flows. The data period covered in the study is from 1991 to 2003, three years before SAFTA became operative, and as a result the regional dummy of their study is capturing the intra-bloc trade creation of the pre-SAFTA regime. Moreover, in the absence of additional dummies, their suggestion about trade diversion in the South Asian bloc is only hypothetical. Dayal et al (2008) estimate the trade potential in South Asia on the basis of a fixed effect gravity equation and predict an average trade potential of 55.7 per cent for the region as a whole.

Weerakoon (2010) considers the shallowness of integration as the root cause of low intraregional trade flow in South Asia and feels anxious that SAFTA might be upstaged by other subregional or bilateral initiatives of the members. The author points out that only 8.4 per cent of LDC (least developed countries) tariff lines and 6.2 per cent of the non-LDC tariff lines fall under the tariff concession scheme. When the complicated nature of bureaucracy that the legal trade channel faces is considered, this small concession has no likely impact on the intra-regional trade flows. Slow progress of SAFTA is forcing members to take alternative routes to liberalization.

The intensity of trade relationship between the South Asian countries with special emphasis on India is analyzed in Raghuramapatruni (2011). Based on a revealed comparative advantage (RCA) index, the author identifies potential commodity groups that could contribute toward enhancing regional trade flows in South Asia. The trade intensity of India with the South Asian countries, calculated for the period 2000 to 2009, shows that the index reached a top of 12.27 per cent in 2003 but then monotonically dropped to 5.54 per cent in 2009. India's recent trade reform along with her increasing ties with the rest of the world, especially with the industrialized countries, is responsible for such changes in the trade intensity pattern. From the comparative advantage perspective, after examining thirteen broad SITC categories, the author concludes that Bangladesh and Sri Lanka have a strong competitive position in clothing (SITC 26), with calculated revealed comparative advantages of 31.464 and 18.129 respectively. However, India and Pakistan are enjoying competitive advantages in Machinery-Transport equipment (SITC 75) with a RCA value of 3.782 and textile sector (SITC 26) with a RCA of 22.649 respectively. Competitive advantages in similar product groups, like agricultural 
commodities for Sri Lanka and India, textile for Pakistan and India, and clothing for Bangladesh and Sri Lanka, highlight the need for regional export diversifications or creation of intra-industry trade as vital for success of the South Asian regional trading bloc.

The shortcomings of the current literature when it comes to evaluating the South Asian free trade area are reflected in their inability to incorporate an appropriate number of regional dummies to investigate the trade creation and the trade diversion effects, as well as the $a d$ hoc or ex ante nature of their analysis. In many cases these studies are based on pre-SAFTA data. In this paper, a suitable version of the gravity model is specified and several panel estimation strategies are applied to assess the ex-post consequences of regional integration initiative for the South Asian countries. The empirical results thus obtained should provide more confidence about the parameters of interest and should provide an improvement over the existing results on the effect of SAFTA on regional trade integration.

\section{Data and Methodology}

\subsection{Description of the Data}

This study exploits a panel of data, where six South Asian countries, India, Bangladesh, the Maldives, Nepal, Pakistan, and Sri Lanka, and the rest of the world (ROW) trading partners as a single unit constitute the cross-section units whose values are observed over the period 1981 to 2012. ${ }^{1}$. In the case of trade of a country with the ROW, the bilateral distance is taken as the average of all the distances between the country and the partners in the ROW, and the GDP of this latter region is taken as the sum of the separate GDPs of its constituent countries. For prices and exchange rate of the ROW, the corresponding US variables are used as proxies.

The data on the relevant variables for estimating the trade flow equation are from various secondary sources. The bilateral trade flow data are from the IMF's Direction of Trade Statistic database. Import figures are expressed c.i.f. (cost, insurance, and freight), while export figures are in f.o.b. (free on board). Both of these variables are in millions of current US dollars. Conversion rates for national currencies with the US dollar are obtained from the International Financial Statistics. The distance measures are from the CEPII (Centre d'Etudes Prospectives et d'Informations Internationales), available on line at www.cepii.fr/../distance.htm and the GDPs, measured in millions of current US dollars, are from the World Development Indicators. Export and import price indices on bilateral basis are not available, so general export and import price indices have been used as their proxy measures.

\footnotetext{
${ }^{1}$ After a thorough analysis of the data, it is found that Bhutan, one of the smallest members of South Asia, lacks some required data and hence is excluded from further analysis.
} 


\subsection{Methodology}

An augmented version of the gravity model suggested in Feenstra (2004) is used here to analyze the impact of SAFTA on trade flow patterns in South Asia. In this context, the chosen model is:

$$
\begin{gathered}
\ln X_{i j}=\beta_{0}+\beta_{1} \ln \left(Y_{i}+Y_{j}\right)+\beta_{2} \ln D_{i j}+\beta_{3} \ln \left(s_{i} s_{j}\right)+\beta_{4} \ln P_{i}+\beta_{5} \ln P_{j} \\
+\beta_{6} \ln E_{i j t}+\beta_{7} R T A 1+\beta_{8} R T A 2+\beta_{9} R T A 3+u_{i j}
\end{gathered}
$$

where $X_{i j}$ is the dollar value of export from country $\mathrm{i}$ to country $\mathrm{j}, Y_{i}$ and $Y_{j}$ are dollar value of nominal GDP of country $i$ and $\mathrm{j}$ respectively. $D_{i j}$ is the physical distance between the two trading partners measured in great circles. $\mathrm{s}_{\mathrm{i}}$ and $\mathrm{s}_{\mathrm{j}}$ represent the share of each of the trading partner's GDP relative to their total GDP, i.e., $s_{i}=\left(G D P_{i} /\left(G D P_{i}+G D P_{j}\right)\right)$ and $s_{j}=\left(G D P_{j} /\left(G D P_{i}+G D P_{j}\right)\right)$.

The product $s_{i} s_{j}$ is a measure of size dispersion between trading partners, first introduced in Helpman (1987). The index monotonically varies from 0 to 0.25 and can be considered as a measure of income convergence between the trading partners. $P_{i}$ and $P_{j}$ are the local and the foreign prices measured by their respective GDP deflators. $\mathrm{E}_{\mathrm{ij}}$ is the exchange rate expressed as the ratio of national currencies per US dollar.

To capture the trade creation and trade diversion consequences of regional integration, the following three dummies are introduced in the regression equation (1) above.

RTA1 $=1$ if trading partners are both in SAFTA, and 0 otherwise $($ SAFTA $\rightarrow$ SAFTA).

(ii) $\quad$ RTA2 $=1$ if importer belongs to SAFTA while the exporter to the RW, and 0 otherwise (ROW $\rightarrow$ SAFTA).

(iii) RTA3 = 1 if the exporter belongs to SAFTA and the importer to the rest of the world, and 0 otherwise (SAFTA $\rightarrow$ ROW).

As the regional bloc SAFTA is operative from 2006, all dummy variables are zero prior to 2006. After 2006, the regional dummy RTA1 gets a value of 1 for exports of SAFTA members to other SFATA members and 0 otherwise. . For exports of from rest of the world (ROW) to SAFTA members RTA2 equals 1 after 2006 and 0 otherwise. Finally, RTA3 equals 1 for exports of SAFTA members to ROW after 2006 and 0 otherwise.

The first dummy is intended to capture the intra-bloc trade effect of the RTA, while the second and the third dummies encapsulate the bloc's effect on import from and export to the ROW, respectively. The coefficients of these three dummies considered together inform us about the nature of trade pattern following regional integration. If increased regional trade (i.e. a positive coefficient of the RTA1 dummy) is accompanied by a fall in import from the ROW (a negative coefficient of the RTA2 dummy), the case of trade diversion arises. A positive coefficient of the latter dummy indicates trade creation. In the case where the second dummy is 
negative and outweighs the positive first dummy, we have pure trade diversion. Otherwise, the diversion is partial and represents a type of import trade diversion. On the other hand, if we substitute the coefficient of the second dummy with the third dummy in the previous interpretation, we have export trade diversion, in which case the ROW suffers.

To introduce dynamics and test for hysteresis effects as suggested by Eichengreen and Irwin (1998), the model is modified to include lagged values of the dependent variable and estimated within a GMM (generalized method of moments) framework. The influence of history in determining trade means that failure to include the lagged dependent variable biases the estimates. However, once the model is made dynamic, simple OLS is inappropriate and hence a dynamic panel data approach is applied with GMM.

\section{Data Analysis, Estimation, Results, and Discussion}

\subsection{Preliminary Data Analysis}

Before analyzing the final model, it is appropriate to examine the data for some basic measures, like mean, standard deviation, skewness and excess kurtosis that will give us a summary idea of the contents of the data. The preliminary data analysis is valuable in evaluating the assumptions of the underlying model, testing for the model's specification validity, and selecting a parsimonious model. The key statistics of the relevant variables in their log form are reported in Table 1. The cross-section observations are stacked one over the other and statistics are calculated over all available observations, with results shown in Table 1.

Table 1: Summary Statistics of the Variables

\begin{tabular}{ccccccc}
\hline \hline Variables & Mean & $\begin{array}{c}\text { Standard } \\
\text { Deviation }\end{array}$ & $\begin{array}{c}\text { Coefficient } \\
\text { of Variation }\end{array}$ & Skewness & $\begin{array}{c}\text { Excess } \\
\text { Kurtosis }\end{array}$ & $\begin{array}{c}\text { Normality } \\
\text { Test }\end{array}$ \\
\hline $\log \left(\mathrm{X}_{\mathrm{ij}}\right)$ & 4.63 & 3.6242 & 0.78 & -0.32 & -0.23 & $26.29(<0.01)$ \\
$\log \left(\mathrm{Yj}_{\mathrm{j}}\right)$ & 26.74 & 2.5477 & 0.10 & 0.72 & -0.81 & $382.07(<0.01)$ \\
$\log \left(\mathrm{s}_{\mathrm{i}} \mathrm{s}_{\mathrm{j}}\right)$ & -2.46 & 3.4365 & 1.39 & -2.24 & 5.50 & $1631.56(<0.01)$ \\
$\log (\mathrm{Dist})$ & 9.05 & 0.05 & 0.50 & -0.57 & 1.83 & $105.72(<0.01)$ \\
$\log \left(\mathrm{P}_{\mathrm{j}}\right)$ & 4.19 & 0.6530 & 0.16 & -0.44 & -0.63 & $96.70(<0.01)$ \\
$\log \left(\mathrm{E}_{\mathrm{ij}}\right)$ & 2.48 & 2.55 & 1.02 & -1.78 & 4.77 & $639.56(<0.01)$ \\
\hline Notes: ${ }^{a}$ Positive excess kurtosis is an indication of leptokurtic (slender with fat tail) distribution, while its \\
negative value implies a platykurtic (broad with thin tail) distribution. ${ }^{b}$ Test for null hypothesis of normal \\
distribution: chi square value (p-values are in parentheses).
\end{tabular}

The overall mean amount of bilateral trade flow in Table 1 is 103 (i.e. $\mathrm{e}^{4.6318}$ ) million US dollars per year. The bilateral trade flow, of course, varies substantially as it incorporates highly dissimilar trading partners. Some details of the bilateral trade flows over each of the three decades covered by our empirical analysis are given in Appendix Table A1. 
Statistics in Table 1 for the shape of the distribution show all the variables, except for the $\log$ of bilateral exports and log of prices, are lepto-kurtic, while, except for the income variable, all are slightly negatively skewed. Since the size of the countries varies widely in South Asia, the values taken by the variables are also more dispersed from the overall mean than a normal distribution would require. The Hansen-Doornik normality test, which takes into account both skewness and kurtosis, also confirms this conclusion in the last column of Table 1 . The null hypothesis of normality is rejected at the 1 per cent level of significance for all these variables. We have two options to deal with the non-normality of the data, either rely on non-parametric tests that do nor require normality assumption or analyze the results based on some kind of robust statistics. The latter approach is followed here, as robust statistics are still parametric and have more power than the former.

\subsection{Time -Series Properties of the Data}

In order to check for the time series properties of the variables in the sample, we employ here various types of panel unit root tests as suggested by Maddala and Wu (1999), Levin, Li and Chu (2002), Im, Pesaran and Shin (2003), and Hadri (2000). These tests differ in terms of their null hypothesis (unit root versus no unit root), inclusion of deterministic terms (individual effect, trend, or none), and methods of auto-correlation correction (lag or kernel based). Except for the Hadri test, which maintains no unit root in the null, all other tests assume the null hypothesis of unit root. Summary results of unit root tests are presented in Table 2.

Test values reported in the third column of Table 2 depend on lag length or bandwidth selection method, both of which are optimally chosen internally by the computer program. The decision as to whether to include a time trend and /or a constant term in the unit root autoregression equation is based on the plot of the respective time series and literature guidance. The test- and probability values show that the variables, except under the Hadri test, are panel stationary at the conventional 5 per cent level of significance. Stable time series properties of the data allow us to use these variables in level form in the trade flow equation estimation. ${ }^{2}$

\footnotetext{
${ }^{2}$ Since these variables are found panel stationary in their log form, they are not first differenced. Over differencing stationary series will result in losing valuable long-term relationship information that is present in the level form of the data.
} 
Table 2: Panel Unit Root Test

\begin{tabular}{|c|c|c|c|}
\hline 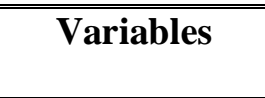 & Test Type & $\begin{array}{c}\text { Statistic } \\
\text { \& Test Value }\end{array}$ & p-value \\
\hline \multirow{4}{*}{$\log \left(X_{\mathrm{ijt}}\right)$} & Maddala-Wu (1999) & $\chi 2=201.49^{a}$ & $<0.001$ \\
\hline & Levin, Lin, and Chu (2002) & $Z=-6.17^{a}$ & $<0.001$ \\
\hline & Im, Pesaran and Shin (2003) & $\mathrm{Z}=-5.13^{\mathrm{a}}$ & $<0.001$ \\
\hline & Hadri (2000) & $\mathrm{Z}=31.0^{\mathrm{a}}$ & $<0.001$ \\
\hline \multirow{4}{*}{$\log \left(Y_{j}\right)$} & Maddala-Wu (1999) & $\chi 2=178.62^{\mathrm{a}}$ & $<0.001$ \\
\hline & Levin, Lin, and Chu (2002) & $\mathrm{Z}=19.72^{\mathrm{a}}$ & $<0.001$ \\
\hline & Im, Pesaran and Shin (2003) & $\mathrm{Z}=12.06^{\mathrm{a}}$ & $<0.001$ \\
\hline & Hadri (2000) & $\mathrm{Z}=97.53^{\mathrm{a}}$ & $<0.001$ \\
\hline \multirow{4}{*}{$\begin{array}{c}\log \left(Y_{i} /\left(Y_{i}+Y_{j}\right)\right. \\
\left.\times\left(Y_{j} /\left(Y_{i}+Y_{j}\right)\right)\right)\end{array}$} & Maddala-Wu (1999) & $\chi^{2}=129.59^{\mathrm{a}}$ & $<0.001$ \\
\hline & Levin, Lin, and Chu (2002) & $\mathrm{Z}=2.25^{\mathrm{a}}$ & 0.024 \\
\hline & Im, Pesaran and Shin (2003) & $\mathrm{Z}=2.87^{\mathrm{a}}$ & 0.004 \\
\hline & Hadri (2000) & $\mathrm{Z}=38.29^{\mathrm{a}}$ & $<0.001$ \\
\hline \multirow{4}{*}{$\log \left(\mathrm{P}_{\mathrm{i}}\right)$} & Maddala-Wu (1999) & $\chi 2=230.06^{b}$ & $<0.001$ \\
\hline & Levin, Lin, and Chu (2002) & $\mathrm{Z}=-8.79^{\mathrm{b}}$ & $<0.001$ \\
\hline & Im, Pesaran and Shin (2003) & $Z=-3.73^{b}$ & $<0.001$ \\
\hline & Hadri (2000) & $\mathrm{Z}=54.74^{\mathrm{b}}$ & $<0.001$ \\
\hline \multirow{4}{*}{$\log \left(P_{j}\right)$} & Maddala-Wu (1999) & $\chi^{2}=230.06^{\mathrm{b}}$ & $<0.001$ \\
\hline & Levin, Lin, and Chu (2002) & $\mathrm{Z}=-8.79^{\mathrm{b}}$ & $<0.001$ \\
\hline & Im, Pesaran and Shin (2003) & $\mathrm{Z}=-3.73^{\mathrm{b}}$ & $<0.001$ \\
\hline & Hadri (2000) & $\mathrm{Z}=54.74^{\mathrm{b}}$ & $<0.001$ \\
\hline \multirow{4}{*}{$\log \left(E_{\mathrm{ij}}\right)$} & Maddala-Wu (1999) & $\chi 2=182.94^{b}$ & $<0.001$ \\
\hline & Levin, Lin, and Chu (2002) & $\mathrm{Z}=3.01^{\mathrm{b}}$ & 0.003 \\
\hline & Im, Pesaran and Shin (2003) & $\mathrm{Z}=3.34^{\mathrm{b}}$ & 0.001 \\
\hline & Hadri (2000) & $Z=54.21^{b}$ & $<0.001$ \\
\hline
\end{tabular}

Notes: (a) The estimated equation contains a drift (constant) term. (b) A trend term is included among the set of dependent variables in the auto-regressive equations.

\subsection{Empirical Model Selection}

In a panel data context it is important to know whether each observation in the data is sufficiently homogenous to be considered as a pooled series. All the individual trade flow and other series over the sample period can be lumped together and the simple OLS strategy can be pursued, if each individual cross-section equation has a similar coefficient structure. However, the presence of country heterogeneity that remains fixed over time suggests the use of panel strategy in the data analysis. The Fisher test statistic suggested in Kunst (2009) confirms the use of panel strategies (random or fixed effect) in this case. In the next step, the Hausman test is applied to select among competing panel estimation methods. The Hausman test statistic turns out to be 6.7058, which is chi-square distributed with 5 degrees of freedom and has a p-value of 0.2435 , implying a preference for the null random effect model. To tackle the endogenity issue in the dynamic panel model, a generalized method of moment (GMM) estimator is used. 


\subsection{Analysis of the Results}

Table 3 summarizes the major findings of the bilateral trade flows from different estimation perspectives. The third and the fourth column represent, respectively, the random effect and the panel general feasible least squares (PGLS) estimation of Equation (1). The fifth column reports the generalized methods of moments (GMM) estimates of the model from the dynamic panel perspective, where an additional auto-regressive term is included among the covariates in the model. In all cases a dummy variable D2009 is used for the year 2009, to account for the disruptive impact of the global financial crisis.

There are a few differences among the estimates obtained under different estimation methods and these arise because of the underlying assumption about the error structure of the equation. While the random effect model exploits only the information on heteroskedasticity in the error, the PGLS is implemented in the context of both heteroskedastic and auto-correlated error structure. The system-GMM controls for the endogenous regressors in the model as well. Thus, the GMM estimates are most reliable, because the exogeneity of the regressors can't be assured.

Coefficients of regressors from the GMM estimates aren't directly comparable to those from the RE and PGLS estimates due to the lagged dependent variable in the GMM estimates. Essentially, the GMM estimates give short-run effects, while the RE and PGLS estimates give long-run effects. However, if the current and lagged values of the dependent variable in the GMM estimates are set equal, their combined coefficient is .05. The coefficients for the other regressors in the GMM estimates are therefore multiplied by 20 (the inverse of .05) to generate equivalent long-run coefficients for comparison with the RE and PGLS estimates.

The signs and significance of the coefficients of the GDPs and the GDP-similarity index are preserved under all these three approaches. The pull of gravity is expected to be stronger, the higher the partners' economic size. Larger economies have capacity to export more or have higher purchasing power to import. Moreover, larger economies permit production at levels to reap scale economies, which is also an important determinant of trade according to the new trade theorists (Krugman, 1980 and Helpman, 1981). 
Table 3: Estimation Results

Dependent variable: $\log$ of bilateral exports, $\log \left(X_{i j t}\right)$

\begin{tabular}{|c|c|c|c|c|}
\hline \multirow[t]{2}{*}{ Variable } & \multirow{2}{*}{$\begin{array}{c}\text { Description } \\
\text { of the Variables }\end{array}$} & \multicolumn{3}{|c|}{ Estimation Methods } \\
\hline & & $\begin{array}{l}\text { RE (One way, } \\
\text { individual) }\end{array}$ & PGLS & $\begin{array}{l}\text { System-GMM } \\
\text { Estimate }\end{array}$ \\
\hline$(1)$ & $(2)$ & (3) & (4) & (5) \\
\hline Constant & Intercept & $\begin{array}{c}-43.09 * * \\
(<0.001)\end{array}$ & $\begin{array}{c}-33.97 * * \\
(<0.01)\end{array}$ & -- \\
\hline $\log \left(X_{i j, t-1}\right)$ & $\begin{array}{l}\text { Log of lagged export form } \mathrm{i} \\
\text { to } \mathrm{j}\end{array}$ & -- & -- & $\begin{array}{l}0.95 * * \\
(<0.01)\end{array}$ \\
\hline $\log \left(Y_{i t}\right)$ & Log of exporter's GDP & $\begin{array}{l}1.34 * * \\
(<0.01)\end{array}$ & $\begin{array}{l}0.83 * * \\
(<0.01)\end{array}$ & $\begin{array}{l}0.02 * * \\
(0.04)\end{array}$ \\
\hline $\log \left(Y_{j t}\right)$ & Log of importer's GDP & $\begin{array}{l}0.86 * * \\
(<0.01)\end{array}$ & $\begin{array}{c}0.61 * * \\
(<0.001)\end{array}$ & $\begin{array}{l}0.03^{*} \\
(0.09)\end{array}$ \\
\hline $\log \left(s_{i t} s_{j t}\right)$ & Log of similarity index & $\begin{array}{l}-0.32 * * \\
(<0.01)\end{array}$ & $\begin{array}{l}-0.68 * * \\
(<0.00)\end{array}$ & $\begin{array}{l}-0.02^{*} \\
(0.06)\end{array}$ \\
\hline $\log \left(D_{i j}\right)$ & $\begin{array}{l}\text { Log of distance between } \\
\text { trading partners }\end{array}$ & $\begin{array}{c}-0.80^{* *} \\
(0.02)\end{array}$ & $\begin{array}{l}0.33 * * \\
(<0.01)\end{array}$ & $\begin{array}{c}-0.11^{* *} \\
(0.02)\end{array}$ \\
\hline $\log \left(E_{i j t}\right)$ & Log of exchange rates & $\begin{array}{l}0.51 * * \\
(<0.01)\end{array}$ & $\begin{array}{l}0.06^{* *} \\
(<0.01)\end{array}$ & $\begin{array}{l}-0.03 * \\
(0.09)\end{array}$ \\
\hline $\log \left(P_{i t}\right)$ & Log of exporter's price & $\begin{array}{l}-0.83^{* *} \\
(<0.01)\end{array}$ & $\begin{array}{l}-0.40^{* *} \\
(<0.01)\end{array}$ & $\begin{array}{c}0.06 \\
(0.30)\end{array}$ \\
\hline $\log \left(P_{j t}\right)$ & Log of importer's price & $\begin{array}{l}-0.18^{*} \\
(0.07)\end{array}$ & $\begin{array}{l}0.25 * * \\
(<0.01)\end{array}$ & $\begin{array}{c}0.04 \\
(0.29)\end{array}$ \\
\hline D2009 & $\begin{array}{c}\text { Global financial crisis } \\
\text { dummy }\end{array}$ & $\begin{array}{l}-0.06 \\
(0.68)\end{array}$ & $\begin{array}{c}0.12 * * \\
(<0.012)\end{array}$ & $\begin{array}{l}-0.24 * * \\
(<0.01)\end{array}$ \\
\hline RTA1 & Regional dummy 1 & $\begin{array}{l}-0.36^{* *} \\
(<0.001)\end{array}$ & $\begin{array}{l}-0.39 * * \\
(<0.001)\end{array}$ & $\begin{array}{c}0.05 \\
(0.35)\end{array}$ \\
\hline RTA2 & Regional dummy 2 & $\begin{array}{c}0.28 \\
(0.13)\end{array}$ & $\begin{array}{l}0.17 * * \\
(<0.01)\end{array}$ & $\begin{array}{c}0.07 \\
(0.18)\end{array}$ \\
\hline RTA3 & Regional dummy 3 & $\begin{array}{l}-0.28 \\
(0.12)\end{array}$ & $\begin{array}{l}0.31 * * \\
(<0.01)\end{array}$ & $\begin{array}{l}0.23 * * \\
(<0.01)\end{array}$ \\
\hline Multiple $\mathrm{R}^{2}$ & Model fit & 0.54 & 0.80 & -- \\
\hline Sarge & ver identification test (chi-squa & with $505 \mathrm{df})(\mathrm{p}-$ & & $\approx 1$ \\
\hline
\end{tabular}

Note: Values in parenthesis are p-values based on robust standard errors.

**, and * indicate parameter estimates significant at 5 per cent and 10 per cent respectively.

The estimated coefficient of both exporter's and importer's GDP are found to be significantly positive in the GMM estimates, with long-run equivalent coefficients of 0.40 and 0.60 (multiplying the coefficients in Table 3 by 20). Thus, for a percentage rise in the GDP of the exporter (importer), bilateral exports rise by 0.40 (0.60) per cent. In the RE estimates, the corresponding coefficients each have a p-value of lower than one per cent and have magnitudes 
of 1.34 and 0.86 for exporters and importers, respectively. The coefficients under the PGLS method are closer to those from the GMM estimates and still highly significant.

The second important control, the log of the product of GDP shares of each country, is designed to capture the effect of the similarity of economic sizes of the partners on their trade flows. The multiplicative form of the GDP share terms restricts the share coefficients for each partner to be equal and this is quite reasonable. The negative coefficient of this variable indicates that dissimilar countries (such as Nepal and India) trade more with each other than countries that are more similar in terms of their economic sizes (such as Bangladesh and Pakistan).

The GMM estimate suggests that for a percentage point improvement toward equality in the income share, bilateral export decreases in the long-run by about 0.40 per cent (the short-run coefficient of -0.02 times 20). The corresponding coefficients in the RE and PGLS estimates are similar and highly statistically significant. This finding is contrary to the Linder's (1961) hypothesis that size similarity between countries leads to preference similarity and overlapping demand which is often responsible for creating bilateral trade in diversified manufacturing products. Because of the low-income status of the South Asian countries and primary production structure, this hypothesis apparently doesn't apply in this region.

The estimated distance coefficient in the long-run is -2.20 and statistically significant under the GMM methodology. Distance is expected to reduce trade in the gravity equation as the economic mass of the distant country is less attractive as a market. The coefficient is positive under the PGLS method, but again is negative under the RE method. The contradictory estimates suggest some variables in the data are endogenous. The GMM method tackles this problem by using instruments from within the model and gives the theoretically expected negative sign for the distance coefficient.

Exchange rates and price levels in both the export and import country are likely to be endogenous in a system with trade flows given that the South Asian countries have flexible exchange rate policies. In the GMM estimates, the price levels of both the exporting and importing country have no statistically significant impact on bilateral trade. However, the relative exchange rate has a statistically significant negative coefficient, indicating that depreciation by the exporter lowers exports, contrary to usual expectation. The sign of this coefficient is opposite under the RE and the PGLS methods, suggesting bias from endogeneity that is controlled in the GMM method.

The final control variable in the bilateral trade results is the dummy variable for the peak of the Global Financial Crisis in the year 2009. The coefficient of this variable in the GMM estimates is -0.24 and highly statistically significant, suggesting that the bilateral trade within 
SAFTA and between SAFTA and ROW fell by almost a quarter in 2009. ${ }^{3}$ The PGLS and RE estimates show positive or statistically insignificant results, respectively, again showing the importance of controlling for endogeneity with the GMM results.

The trade creation and trade diversion consequences of regional trade liberalization in South Asia through their SAFTA initiative can be analyzed with the help of the coefficient estimates of the three regional dummies. Trade creation occurs when extra trades are generated among the members, as they remove their tariff and non-tariff barriers at the regional level. In a regionally protected market members find it cheaper to source their imports from within the free trade area. Though producers in the rest of the world are more efficient, once external tariffs are taken into account, outsiders are in a competitive disadvantage position in the regional market and trade diversion results.

Possible scenarios for new trade patterns that may emerge from regional integration are shown in Table 4, where an up (down) arrow in a cell indicates rise (fall) in export from the source to the destination region.

Table 4: Classification of Trade Flow Changes Based on Import Source and Export Destination

\begin{tabular}{|c|c|c|}
\hline Destination & South Asia & Rest of the World \\
\hline South Asia & $\uparrow=$ Trade Creation & $\uparrow=$ Trade Creation \\
$\downarrow=$ Dysfunctional Integration & $\downarrow=$ Import Trade Diversion \\
\hline Rest of the World & $\begin{array}{c}\text { S }=\text { Trade Creation } \\
\downarrow=\text { Export Trade Diversion }\end{array}$ & Not Applicable \\
\hline
\end{tabular}

The nature of trade creation and trade diversion effects of the SAFTA can be understood in the light of the estimated three regional dummy coefficients. To avoid misinterpretation, the coefficients of the dummies need to be explained in the context of a semi-log regression model where the exact percentage change in the dependent variable due to the presence of a particular attribute in the dummy variable is measured as $[100 \times(\exp (\hat{\beta})-1)]$, and, following the delta method, the asymptotic standard error is computed with $[100 \times \exp (\hat{\beta}) \times \operatorname{se}(\hat{\beta})]$ (Wooldridge, 2002).

\footnotetext{
${ }^{3}$ The dummy for 2009 has a value of 1 only in 2009, so it only has a short-run impact on bilateral exports.
} 
The coefficient of RTA1 measures the additional trade flow among the members in the free trade area regime compared to the non-preferential era or trade with non-members. In general, because of reduced trade barriers, the coefficient of this variable is hypothesized to be positive. The estimated coefficient of RTA1 is positive but not statistically significant in the GMM estimates, suggesting no clear relationship between the formation of SAFTA and trade flows among members. It is worth noting that the estimated coefficient of this dummy is negative and highly statistically significant in the RE and PGLS estimates, pointing again to the importance of controlling for endogeneity in the regressors through the use of GMM methodology.

Intra-regional trade in South Asia through the SAFTA falls far behind than what one might expect under a free trade area, where it is implicitly assumed that there will be no barriers to trade among the members. The phased introduction of SAFTA provisions through 2016 means there has been scanty coverage of tariff lines under the agreement. Also inhibiting trade is that food and textile items - two major product of export interest for the members - are in the sensitive list and excluded from concessions. Furthermore, the widespread use of para-tariff (e.g. infrastructure development surcharge) and non-tariff measures like government regulations, antidumping measures, import licenses and sanitary standards severely impedes trade flows within this region. ${ }^{4}$

The estimated coefficients of the RTA3 dummy is highly significant and positive in the GMM methods, implying that the South Asian countries have increased their exports to the outside region during the post-SAFTA period. Trade creation has occurred since the formation of SAFTA, but with non-member countries rather than within the bloc. Together with the positive, but statistically insignificant, coefficient of RTA2, there is certainly no support for a finding of trade diversion. Rather, the results from the three RTA dummy coefficients suggest that through 2012 SAFTA has been a largely ineffective preferential trading agreement operating during a period of strong outward orientation of member countries. ${ }^{5}$

\section{Conclusions}

Our research investigates the impact of the current free trade agreement in South Asia in changing the trade patterns of the member states. Within an extended gravity model framework and with relevant data from the concerned countries, the empirical results show that SAFTA has not been effective in producing additional trade flow within the region. This result is not

\footnotetext{
${ }^{4}$ Sawhney and Kumar (2008) point to political disputes over unresolved territorial issues, as the root cause of turning South Asia into the least integrated region of the world. They note that on one occasion Pakistan even denied India the MFN (Most Favored Nation) benefits, though both are WTO members.

${ }^{5}$ The corresponding RE and PGLS estimates show different patterns of RTA coefficients (both from each other and from the GMM estimates. However, the RE and PGLS results fail to control for endogenous regressors.
} 
surprising given the limited scope and, so far, only partial implementation of the agreement. An agreement that promotes deeper integration of the economies is required if intra-regional trade is to be boosted substantially.

Three different estimation methods are used in our empirical analysis: random effects controlling for heteroskedasticity, panel estimation controlling for heteroskedasticity and autocorrelation, and the generalized method of moments (GMM) applied to a dynamic specification of the estimating relationship (with controls for heteroskedasticity, autocorrelation and endogenous regressors). The three methods generate broadly similar positive estimates for the long-run effects of importer and exporter GDP and, also, similar negative estimates for the long-run effect of similarity of size of exporting and importer GDP. These results support the gravity hypothesis that economic mass encourages trade, with differences in size encouraging even more trade.

For the remaining control variables in the estimating equation and for the dummy variables that capture the effects after the formation of SAFTA, there are notable differences in the magnitude, sign and statistical significance of corresponding coefficients across the three estimating methods. The conceptually most appropriate results from applying the GMM approach to a dynamic specification with the lagged dependent variable as a regressor, shows the importance of controlling for the history of bilateral trade as suggested by Eichengreen and Irwin (1998). These results also show that distance between trading partners has the expected negative effect on bilateral trade and that bilateral trade declined by almost one quarter during 2009 at the peak of the GFC. Finally, these results show that trade has generally increased since the formation of SAFTA, although the only statistically significant increase has been in the exports of SAFTA members to the rest of the world.

It should be noted that only the trade-flow effects of SAFTA have been considered in this study, which need not validate or nullify the desirability of the agreement. Regional cooperation often involves multi-dimensional objectives. Enhanced political cooperation, credibility of policy reforms, or consideration of dynamic gains from trade can produce substantial benefits. Furthermore, while regional integration in South Asia has been generally ineffective in promoting intra-regional trade flows, at least the region continues to move towards integration into the broader global economy. Trade creation, rather than trade diversion, is clearly indicated in our results for the post-SAFTA period. 


\section{References}

Athukorala, P. C., and N. Yamashita. 2008. Patterns and determinants of production fragmentation in world manufacturing trade. In F. d. Mauro, S. Dees and W. J. McKibbin, eds. Globalisation, Regionalism and Economic Interdependence. Cambridge: Cambridge University Press: 45-72.

Bhagwati, J., and A. Panagariya. 1996. Preferential trading areas and multilateralism: Strangers, friends or foes? In J. Bhagwati and A. Panagariya, ed. Economics of Preferential Trade Agreements. Washington, DC: AEI Press: 1-78.

Bun, M., F. Klaassen, and R. Tan. 2007. Free Trade Areas and Intra-regional Trade: The Case of ASEAN. Discussion Paper: 2007/04, Amsterdam School of Economics, University of Amsterdam.

Cipollina, M., and L. Salvatici. 2010. Reciprocal Trade Agreements in Gravity Models: A Metaanalysis. Working Paper 06/12, TRADEAG Project, Luxemburg: European Commission.

Coulibaly, S. 2004. On the Assessment of Trade Creation and Trade Diversion Effects of Developing RTAs. Paper Presented at the Swiss Society of Economics and Statistics on Resource Economics, Technology and Sustainable Developmnet (available at http://www.wif.ethz.ch/resec/sgvs/078.pdf, accessed on March 18, 2012).

Dayal, P., A. Das, R. Banga, K. Iyengar, and S. Ahmed. 2008. Quantification of Benefits from Economic Cooperation in South Asia. Asian Development and United Nations Conference on Trade and Development, New Dehli: Macmillan Publishers.

Deardorff, A. V. 2001. Trade and Welfare Implication of Networks. Paper Presented at the Murray S. Johnson Conference on International Economics. University of Texas, April 28-29.

Direction of Trade Statistics. 2013. Direction of Trade Statistics. Washington: International Monetary Fund.

Eichengreen, B., and D. A. Irwin. 1998. The Role of History in Bilateral Trade Flows. In J.A. Frankel, ed. The Regionalization of the World Economy. New York: National Bureau of Economic Research: 33-62

European Commission. 1997. Trade Creation and Trade Diversion. The Single Market Review, Sub-Series 4, Volume 3. Luxembourg: European Commission.

Feenstra, R. C. 2004. Advanced International Trade: Theory and Evidence. Princeton, NJ: Princeton University Press.

Frankel, J. A., E. Stein, and S.-J. Wei. 1996. Regional trading arrangements: natural or supernatural? American Economic Review 86 (2): 52-56.

Glick, R., and A. K. Rose. 2002. Does a currency union affect trade? The time-series evidence. European Economic Review 46 (6): 1125 - 1151.

Hadri, K. 2000. Testing for unit roots in heterogenous panel data. Econometrics Journal 3 (2): $148-161$.

Hassan, M. K. 2001. Is SAARC a viable trading block? Evidence from gravity model. Journal of Asian Economics 12 (2): 263-290.

Helpman, E. 1981. International trade in the presence of product differentiation, economies of scale and monopolistic competition: A Chamberlin-Heckscher-Ohlin approach. Journal of International Economics 11 (3): 305-340.

-------. 1987. Imperfect competition and international trade: Evidence from fourteen industrial countries. Journal of the Japanese and International Economies 1 (1): 62-81. 
Im, K. S., M. H. Pesaran, and Y. Shin. 2003. Testing for unit roots in heterogenous panels. Journal of Econometrics 115 (1): 53-74.

Krugman, P. 1980. Scale economies, product differentiation, and the pattern of trade. American Economic Review 70 (5): 950-959.

Kunst, R. M. 2009. Econometric method of panel data - Part-II. University of Vienna, available at http://homepage.univie.ac.at/...kunst/panel2e.html, accessed February 2, 2012.

Levin, A., C. F. Lin, and C. S. J. Chu. 2002. Unit root tests in panel data: Asymptotic and finite sample properties. Journal of Econometrics 108 (1): 1-19.

Linder, B. 1961. An Essay on Trade and Transformation. Stockholm: Almqvist \& Wicksell.

Maddala, G. S., and S. Wu. 1999. A comparative study of unit root test with panel data and a new simple test. Oxford Bulletin of Economics and Statistics 61 (Supplement 1): 631652.

Panagariya, A. 1996. The Free Trade Area of the Americas: Good for Latin America? World Economy 19 (5): 485-515.

Raghuramapatruni, R. 2011. The experience of SAARC as a regional block and its future potentialities. Indian Journal of Economics \& Business 10 (1): 57-72.

Rahman, M., W. B. Sadat, and N. C. Das. 2006. Trade Potential in SAFTA: An Application of Augmented Gravity Model. Centre for Policy Dialogue Paper 61.

Sawhney, A., and R. Kumar. 2008. Why SAFTA?, Jaipur: CUTS International, Commonwealth Secretariat.

Sawyer, W. C., R. L. Sprinkle, and K. Tochkov. 2010. Patterns and determinants of intraindustry trade in Asia. Journal of Asian Economics 21 (5): 485-493.

Weerakoon, D. 2010. SAFTA: Current status and prospects. In Beyond SAFTA, Washington D.C.: World Bank.

Wonnacott, R. J. 1996. Association free-trade agreements: For better or worse? American Economic Review 86 (2): 62-66.

Wooldridge, J. M. 2002. Econometric Analysis of Cross Section and Panel Data. Cambridge, MA: MIT Press.

World Bank. 2004. Trade Policies in South Asia: An Overview. Vol. II, Washington: World Bank.

2005. End of MFA Quotas: Key Issues and Strategic Options for Bangladesh Readymade Garment Industry Bangladesh Development Series - Paper no 2, Dhaka: World Bank Office. 


\section{Appendix}

Table A1: Structure of Regional Trade in South Asia

(Values in million US dollars, current prices)

\begin{tabular}{|c|c|c|c|c|c|c|c|c|c|c|}
\hline Country & $\begin{array}{l}\text { Year } \\
\text { (Avg) }\end{array}$ & $\begin{array}{l}\text { Regional } \\
\text { Import }\end{array}$ & $\begin{array}{c}\text { Total } \\
\text { Import }\end{array}$ & $\begin{array}{l}\% \text { of } \\
\text { Total }\end{array}$ & $\begin{array}{c}\text { Regional } \\
\text { Export }\end{array}$ & $\begin{array}{c}\text { Total } \\
\text { Export }\end{array}$ & $\begin{array}{l}\% \text { of } \\
\text { Total }\end{array}$ & $\begin{array}{c}\text { Regional } \\
\text { Trade }\end{array}$ & $\begin{array}{l}\text { Total } \\
\text { Trade }\end{array}$ & $\begin{array}{l}\% \text { of } \\
\text { Total }\end{array}$ \\
\hline \multirow{3}{*}{ Bangladesh } & 1981-90 & 1206.8 & 28168.4 & 4.28 & 647.5 & 10446.4 & 6.20 & 1854.3 & 38614.8 & 4.80 \\
\hline & 1991-00 & 8298.8 & 60900.9 & 13.63 & 746.8 & 32637.5 & 2.29 & 9045.6 & 93538.4 & 9.67 \\
\hline & 2001-12 & 35478.5 & 230569.2 & 15.39 & 3622.5 & 147683.3 & 2.45 & 39101.0 & 378252.5 & 10.34 \\
\hline \multirow{3}{*}{ India } & 1981-90 & 1034.8 & 169734.6 & 0.61 & 3171.2 & 106224.1 & 2.99 & 4206.0 & 275958.7 & 1.52 \\
\hline & 1991-00 & 2317.7 & 341297.0 & 0.68 & 12934.7 & 291978.2 & 4.43 & 15252.4 & 633275.2 & 2.41 \\
\hline & 2001-12 & 15785.4 & 2679728.1 & 0.59 & 86196.9 & 1815577.0 & 4.75 & 101982.3 & 4495305.1 & 2.27 \\
\hline \multirow{3}{*}{ Pakistan } & 1981-90 & 1092.2 & 60414.4 & 1.81 & 1499.2 & 35964.7 & 4.17 & 2591.4 & 96379.1 & 2.69 \\
\hline & 1991-00 & 1907.9 & 101733.5 & 1.88 & 2751.2 & 79486.1 & 3.46 & 4659.1 & 181219.6 & 2.57 \\
\hline & 2001-12 & 15730.4 & 376381.7 & 4.18 & 8328.8 & 207854.6 & 4.01 & 24059.2 & 584236.3 & 4.12 \\
\hline \multirow{3}{*}{ Sri Lanka } & 1981-90 & 1345.9 & 20039.4 & 6.72 & 716.7 & 13167.0 & 5.44 & 2062.6 & 33206.4 & 6.21 \\
\hline & 1991-00 & 5430.5 & 48480.9 & 11.20 & 1051.3 & 38232.0 & 2.75 & 6481.8 & 86712.9 & 7.48 \\
\hline & 2001-12 & 29195.8 & 131335.4 & 22.23 & 6242.9 & 89752.6 & 6.96 & 35438.7 & 221088.0 & 16.03 \\
\hline \multirow{3}{*}{ Nepal } & 1981-90 & 847.8 & 3571.9 & 23.74 & 373.8 & 1352.4 & 27.64 & 1221.6 & 4924.3 & 24.81 \\
\hline & 1991-00 & 2631.3 & 10113.0 & 26.02 & 945.0 & 4149.7 & 22.77 & 3576.3 & 14262.7 & 25.07 \\
\hline & $2001-12$ & 20071.4 & 35460.7 & 56.60 & 5912.6 & 9301.2 & 63.57 & 25984.0 & 44761.9 & 58.05 \\
\hline \multirow{3}{*}{ Bhutan } & 1981-90 & N/A & 843.6 & N/A & N/A & 393.2 & N/A & N/A & 1236.8 & N/A \\
\hline & 1991-00 & N/A & 1317.5 & N/A & N/A & 933.6 & N/A & N/A & 2251.1 & N/A \\
\hline & $2001-12$ & N/A & 4246.1 & N/A & N/A & 3470.7 & N/A & N/A & 7716.8 & N/A \\
\hline \multirow{3}{*}{ Maldives } & 1981-90 & 110.3 & 893.7 & 12.34 & 40.4 & 263.0 & 15.37 & 150.7 & 1156.8 & 13.03 \\
\hline & 1991-00 & 552.4 & 2914.8 & 18.95 & 115.9 & 622.0 & 18.64 & 668.3 & 3536.8 & 18.90 \\
\hline & 2001-12 & 1736.3 & 11140.6 & 15.59 & 259.7 & 1649.9 & 15.74 & 1996.0 & 12790.5 & 15.61 \\
\hline \multirow{3}{*}{$\begin{array}{l}\text { South } \\
\text { Asia }\end{array}$} & 1981-90 & 5637.9 & 282822.5 & 1.99 & 6448.8 & 167417.6 & 3.85 & 12086.6 & 450240.1 & 2.68 \\
\hline & 1991-00 & 21138.7 & 565440.1 & 3.74 & 18544.8 & 447105.4 & 4.15 & 39683.5 & 1012545.5 & 3.92 \\
\hline & 2001-12 & \begin{tabular}{|l|}
117997.8 \\
\end{tabular} & 3464615.8 & 3.41 & 110563.4 & 2271818.5 & 4.87 & 228561.1 & 5736434.3 & 3.98 \\
\hline
\end{tabular}

Source: Authors calculations

Note:

- Figures are arithmetic mean over the period indicated in column two

- N/A: Not available.

- Figures for South Asia average excludes Bhutan 